\title{
Combining Methods to Establish Potential Management Measures for Invasive Species Elodea nutallii in Lough Erne Northern Ireland
}

\author{
Timohty G. O'Higgins, Fiona E. Culhane, Barry O'Dwyer, \\ Leonie A. Robinson, and Maneul Lago
}

\begin{abstract}
Lough Erne (Northern Ireland) is a heavily modified water body in a transnational catchment, straddling Northern Ireland (in the U.K.) and the Republic of Ireland. The lake has a long history of human modification from hydroelectrification, eutrophication and the introduction of non-native species. Most recently the proliferation of the non-native pond weed Elodea nutalli has adverse implications for recreational users of the lake. In order to establish management measures which might be acceptable to a range of lake, a number of methods, using a mixture of disciplines were combined. Fuzzy cognitive mapping exercises combined with formal goal identification surveys were conducted to establish consensus on the main environmental problems and conflicts. GIS was used to visualise potential management scenarios. Management scenarios were costed and presented to lake users to establish the preferred measures. The overall process promoted discussion and awareness of different uses and user perspectives to enable development of consensus.
\end{abstract}

\section{Lessons Learned}

- Loose coupling of models provided a useful means of analysing the system in a data poor situation

- Co-design of the models enabled the development of consensus

- Visual representation through maps and graphs enabled the communication of complexity

- Including the full suite of stakeholders is ideal but we were unable to compel unwilling stakeholders

T. G. O'Higgins $(\bowtie) \cdot$ B. O’Dwyer

MaREI, Environmental Research Institute, University College Cork, Cork, Ireland

e-mail: tim.ohiggins@ucc.ie

F. E. Culhane $\cdot$ L. A. Robinson

School of Environmental Sciences, University of Liverpool, Liverpool, UK

M. Lago

Ecologic Institute, Berlin, Germany

(C) The Author(s) 2020

T. G. O'Higgins et al. (eds.), Ecosystem-Based Management, Ecosystem Services and Aquatic Biodiversity, https://doi.org/10.1007/978-3-030-45843-0_23 
- Mechanisms to promote improved farm management have the potential to enable solutions where both farmers and the environment benefit.

\section{Needs to advance EBM}

- In the context of the Erne as a transboundary system the importance of developing inclusive stakeholder fora to enable transboundary cooperation is one important requirement.

- More integrated quantitative modelling of the hydrological system and the nutrient fluxes could enhance the evidence base for action.

- Development of socially inclusive stakeholder processes.

\section{Introduction}

Ecosystem-Based Management (EBM) has been defined as an approach to management which "integrates the connections between land air water and all living things, including human beings and their institutions" (Mee et al. 2015), as such EBM in a particular location must incorporate considerations of both social and ecological aspects of that Social-Ecological System (SES). For any given system, what may be ecologically desirable to some, may be socially unacceptable to others, and different management options may result in costs or benefits to different sectors in society resulting in trade-offs or conflicts. In transboundary systems these costs and benefits may accrue in different jurisdictions, resulting in governance challenges and adding a further layer of complexity to effective management of a particular problem. In addition, achievement of socially desirable management end points may be constrained by the ecological properties of a given system. Very often there is a great degree of uncertainty about how effective a particular management measure might be, resulting in the need for adaptive management or a learning by doing approach (Holling 1978). Thus developing realistic and appropriate management strategies and targets relies on knowledge of both the ecological functioning of a system and the objectives of different users of a system, including the legislative objectives for environmental state and economic development.

The spread of Invasive Alien Species is considered a major threat to biodiversity the UN Convention on Biodiversity Strategic Plan for biodiversity (CBD 2014). In Europe, under the regulation of Invasive Alien Species (IAS) (EC 2014), a list of IAS of union concern has been drawn. The regulation forbids the transport or trade of the listed species. Member States are required to set out action plans on the pathways of invasion and to put in place surveillance systems and effective management measures for those species found to be widespread. Where an ecosystem is deemed to be "degraded, damaged or destroyed" the ecosystem must be restored unless costs of restoration are disproportionately high compared to the benefits.

Lough Erne, Co. Fermanagh Northern Ireland (NI), is comprised of Upper Lough Erne and Lower Lough Erne, both widened channels of Ireland's second largest 
river, the Erne. The lakes are in Northern Ireland but a substantial part of the catchment is situated within the Republic of Ireland (Fig. 1) and the region has a legacy of social and cultural division and conflict. The Erne is also connected to the

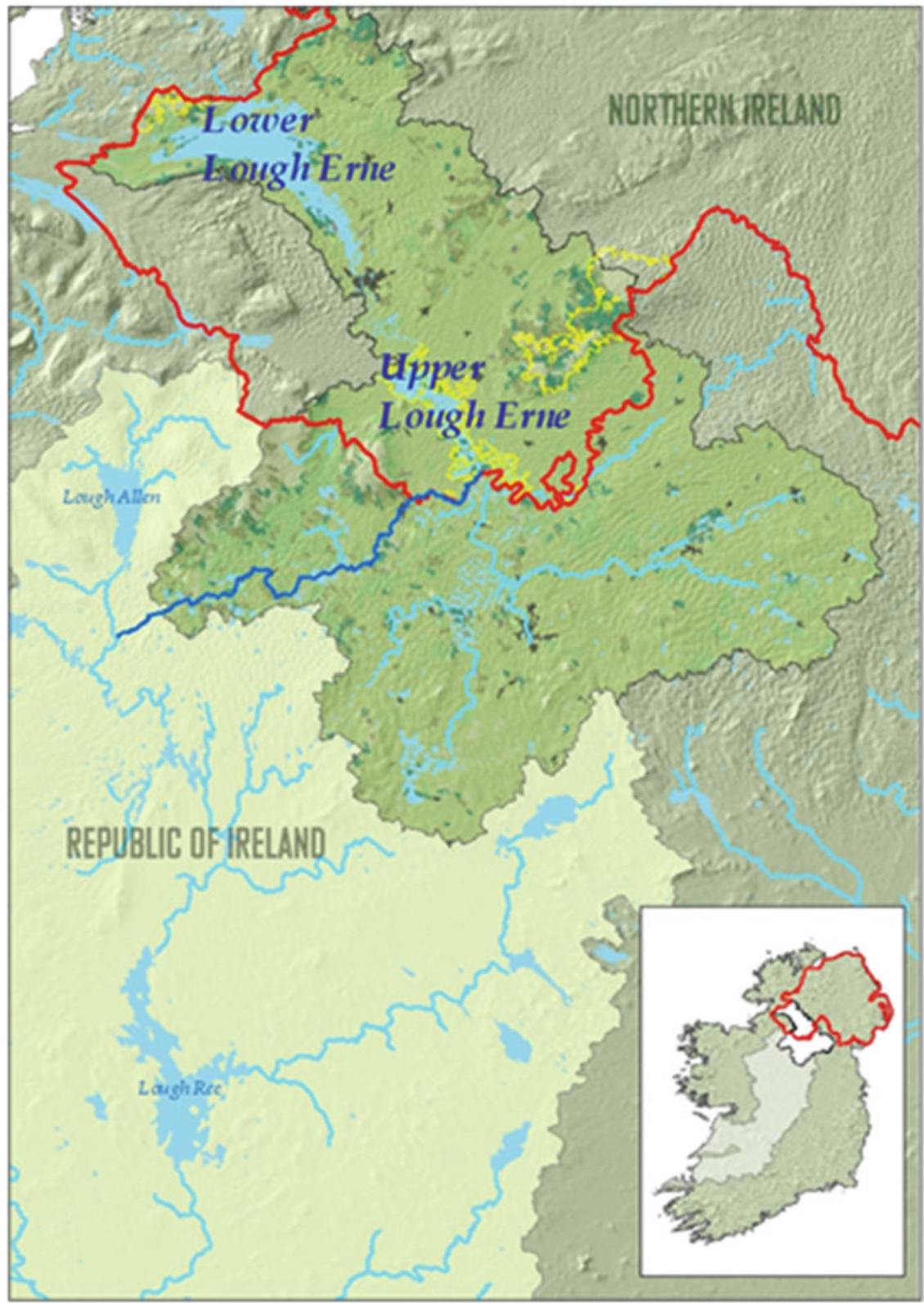

Map of Lough Erne showing the international border (red) as well as the Catchment (inset white) and the its connection with the Shannon catchment (inset light green)

Fig. 1 Map of the study area, showing Upper Lough Erne SAC and international border 
Shannon river basin (the largest on the island) by the Shannon Erne Waterway. Due to this international connectivity, management of invasive species in Lough Erne is critical to the management of freshwater biodiversity across the entire island of Ireland.

The Lough Erne system has been settled since neolithic times and the ecology of the lake has been shaped by human society for millennia (Lafferty et al. 2006). References to the Erne fisheries date back to mythology and the oral tradition of early Christian times (Went 1945). In so far as a natural state can be determined for the Erne system, the fish fauna of the lake is naturally depauperate, comprised of post-glacial relic species (Salmonids, pollan and eel) supplemented by historically introduced species, including, bream, perch and pike (Rosell 2001). ${ }^{1}$ Scientific records of non-native species date back to the late nineteenth century when Canadian pond weed (Elodea canadenis) was first recorded, (Moore and More 1866). Upper Lough Erne is particularly prized for its flora and fauna having several national and international environmental designations. Agriculture is also vitally important in the surrounding catchment and the lake has a history of eutrophication associated with agriculture in the catchment and associated fertilizer runoff (Battarbee 1986). It is currently considered moderately eutrophic under the EU Water Framework Directive (EC 2000). The lake supports a wide range of recreational activities, in particular boating and fishing are major contributors to the local tourist industry. Since the 1950s, the lake has been harnessed for hydro-electricity production. When constructed, the hydro power stations provided benefits to the government of the Republic of Ireland in their drive for rural electrification and to the people of Northern Ireland in the management of flooding. At the time, the Erne Drainage and Development Act (1950) which enabled the construction was an unprecedented example of cross-border cooperation.

There have been a number of recent invasive species introductions to the lake (Gallagher et al. 2015, Minchin et al. 2016) with the most significant being the zebra mussel (Dreisenna polymorpha) (Rosell et al. 1999; Maguire et al. 2006). The recent proliferation of Nutall's pond weed (Eldoea nuttalli) is a particular problem for tourism because it interferes with recreational boating and fishing. The growth of the pond weed is facilitated by the high nutrient levels of the lake waters and exacerbated by the high water transparency caused by the filter feeding of the zebra mussel (Kelly et al. 2015). This physical removal of the already established weed is costly (Kelly et al. 2013) and has proved ineffective in controlling its spread.

The aim of this paper is to describe the application of a flexible multi-disciplinary methodology in Lough Erne to demonstrate and communicate the utility of EBM practices to meet the needs of lake users and enable development and communication of Ecosystem-Based Management objectives and trade-offs which meet the needs of lake users and mangers within the system.

\footnotetext{
${ }^{1}$ Pike are known in the Irish language as "Gall Iasc" translating to "French" or "Foreign Fish" suggesting a Norman origin in Ireland's waters (ca. 1000 bp).
} 


\section{Materials and Methods}

The overall approach to EBM was based on the "butterfly" assessment framework which is detailed in Elliott and O'Higgins (2020). An initial scoping meeting was held with stakeholders in the Lough Erne Invasive Species Working Group (LEISWG) (an informal collective of interested parties including several government agencies) and a second stakeholder workshop was held with participation from a variety of organisations from both Northern Ireland and the Republic of Ireland, including state agencies, national and local government as well as non-governmental organisations. The formal analysis of stakeholder goals at this meeting is described in Robinson et al. (2019) and the goals identified through that analysis formed the basis of a Fuzzy Cognitive Mapping exercise.

Fuzzy Cognitive Maps (FCM) are semi-quantitative models of system operation based on an individual's/individual stakeholder group perception of the structure and function of a given problem or system. An FCM is a diagraph or directed graph made up of variables (points, nodes or concepts), and relationships between these concepts (links or edges), or, put simply boxes and weighted arrows. Positive or negative values are assigned to these relationships and expressed as a fraction of one based on the perceived strength of the relationship. FCM has been widely applied to a range of situations; it can be used to build models of system behaviour based on expert opinion and can be used to build consensus amongst stakeholders, as well as to develop predictions for system function based on scenarios. Özesmi and Özesmi (2004) describe the mathematical aspects as well as a range of different approaches to developing FCMs.

Five separate Lough Erne stakeholder groups participated at a workshop to produce FCMs; these included, environmental NGOs and conservation groups, water managers, hydro-electricity producers and wildfowling groups as well as local government organisations. While there was high level participation by the Northern Ireland Department of Agriculture, despite invitation, farmers groups themselves chose not to attend. The DPSIR (see Elliott and O'Higgins 2020) was used as an organisational frame to elicit concepts and connections from participants. Each FCM was generated by starting with a particular Driver within the SES which interfered with the objectives of specific groups (see Robinson et al. 2019), the specific components were agreed by the groups and acted as a starting point for the FCMs. Each FCM was written on a whiteboard and relationships between all concepts identified were considered and assigned a positive or negative weight. Following the workshop the FCMs were photographed and then rendered electronically using Mental Modeller software (http://www.mentalmodeler.org/) before export. Matrices, output from Mental Modeller, from each group were combined (in Microsoft Excel) to develop a joint matrix representing the overall FCM of the whole group (called the JOINT FCM). The open source software GEPHI (https:// gephi.org/) was used to visualise the data. Analysis of the FCM was carried out in R using the FCM modeller library (https://CRAN.R-project.org/package=FCMapper). In order to develop a consensus map, it was necessary to harmonise concepts within 
the maps. For example, concepts such as "fish stock salmonids" and "game fish" were amalgamated as were "fish stock cyprinids" and "coarse fish". To generate a final consensus map, the weight of each connection was determined by summing the weights of all connections from each contributing map. Only consensus connections from one or more groups contributed to the final map, reducing the complexity of the model from the 55 nodes of the original combined model to a final consensus model containing just eleven nodes. The baseline conditions general direction of change based on stakeholder understanding were determined by allowing the model to run to steady state. To assess the sensitivity of the systems to changes in different components 11 different model runs were performed, for each, one of the eleven model components was fixed to its initial state and the effects on all other components were examined (Table 1).

Based on the consultation process with the LEISWG, specific measures to manage the pond weed by manipulation of lake levels were identified. These measures were designed to manage the impact of pond weed proliferation on recreational activities within the lake, by controlling the amount of light available to the weed as well as increasing the draft between recreational vessels and the weed (Fig. 2). The spatial consequences of these measures were assessed using GIS. The EURODEM Digital Elevation Model (horizontal resolution $25 \mathrm{~m}$ ) GIS was used to identify cells within a $5 \mathrm{~km}$ distance of the Lough with elevations marginally greater than the lake level. The Erne Drainage and Development Act (1950) stipulates strict limits for the lake levels during the summer season, between $150 \mathrm{ft} .(45.7 \mathrm{~m})$ and $154 \mathrm{ft}$. (46.9 m) above sea level), a range of approximately $1.2 \mathrm{~m}$. The location and extent of potentially flooded lands was simulated at 5 increments from $0.2 \mathrm{~m}$ to a level of $1.2 \mathrm{~m}$ above the lake levels of the Digital Elevation Model, corresponding to the legally determined limits of lake water levels which are legally determined.

Table 1 Model components showing positive or negative changes $>1 \%$ in the sensitivity analysis, affector components and the size of effect

\begin{tabular}{l|l|r}
\hline Component & Affector & Effect \\
\hline Water quality & Components & $\%$ \\
\hline & Agriculture & -18 \\
\hline & Forestry & -15 \\
\hline & IAS & -14 \\
\hline Habitat & Habitats & 11 \\
\hline & Tourism & -1 \\
\hline Biodiversity & Water quality & 9 \\
\hline & Conservation & 9 \\
\hline Tourism & Water quality & 6 \\
\hline & Habitat & 4 \\
\hline & Water quality & 2 \\
\hline Agriculture & Conservation & 1 \\
\hline & IAS & -1 \\
\hline Flood management & Conservation & 2 \\
\hline & Flood management & 2 \\
\hline & Habitat & 3 \\
\hline
\end{tabular}




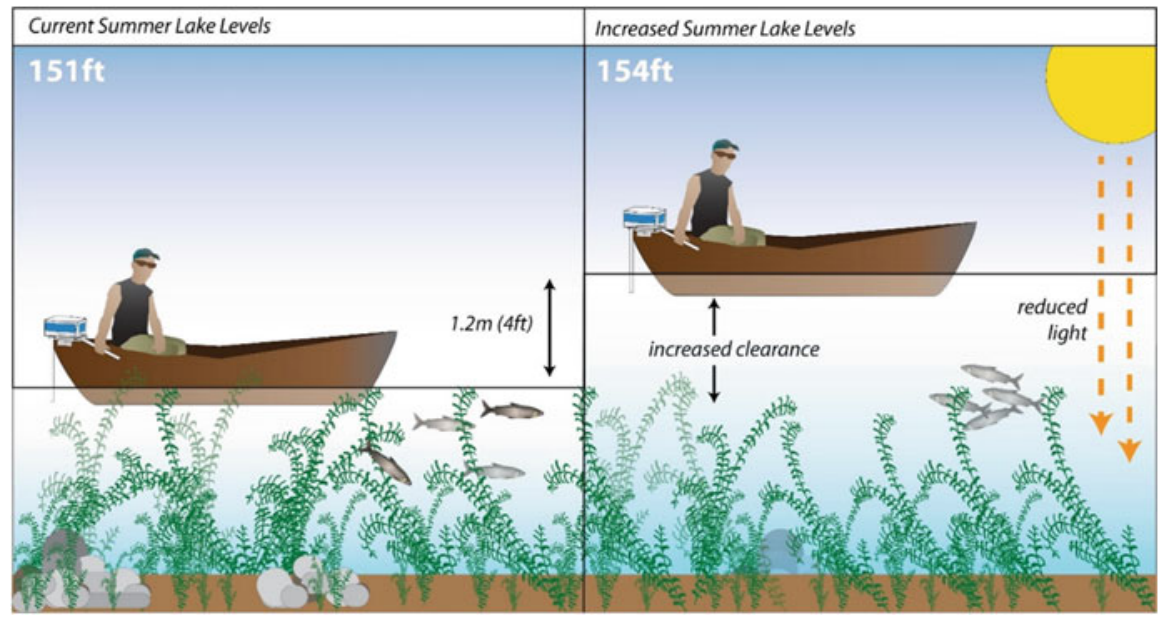

Fig. 2 Illustration of how raised lake levels could result in potential improvements for recreational boating

Economic valuation was used to appraise the costs of potential management measures. The costs to agriculture of raising lake levels were estimated in terms of annual standard output from the NI annual farm census and in terms of land value based on compulsory purchase price.

Based on the results of the fuzzy cognitive mapping exercise, valuation of a variety of agricultural measures to reduce nutrients was also performed, benefits transfer was based on Cuttle et al. (2007), these authors reviewed a range of farm Best Management Practices (BMPs) to reduce diffuse water pollution from agriculture, describing in detail the costs and technical effectiveness of each measure. Using a Cost Effectiveness Analysis (CEA) method, BMPs that could be implemented at least cost for the farmer while maximising potential Phosphorus $(\mathrm{P})$ reductions were identified. The cost curve method was subsequently applied (Lago 2009) to estimate levels of abatement that could be potentially achieved as BMPs are sequentially added at farm level while considering their financial costs. The costs were calculated for two targets, $30 \%$ reduction in nutrient concentrations and $70 \%$ reduction in nutrients at the farm level under the assumption that the reductions would translate proportionally into improvements in water quality.

\section{Results}

Figure 3 illustrates the results of the joint FCM showing all 55 Drivers, Pressures and Ecosystem components considered by stakeholders to contribute to the functioning of the system. The concepts are scaled by the number of connections (known as density in the language of FCM). It is immediately apparent that agriculture, tourism 


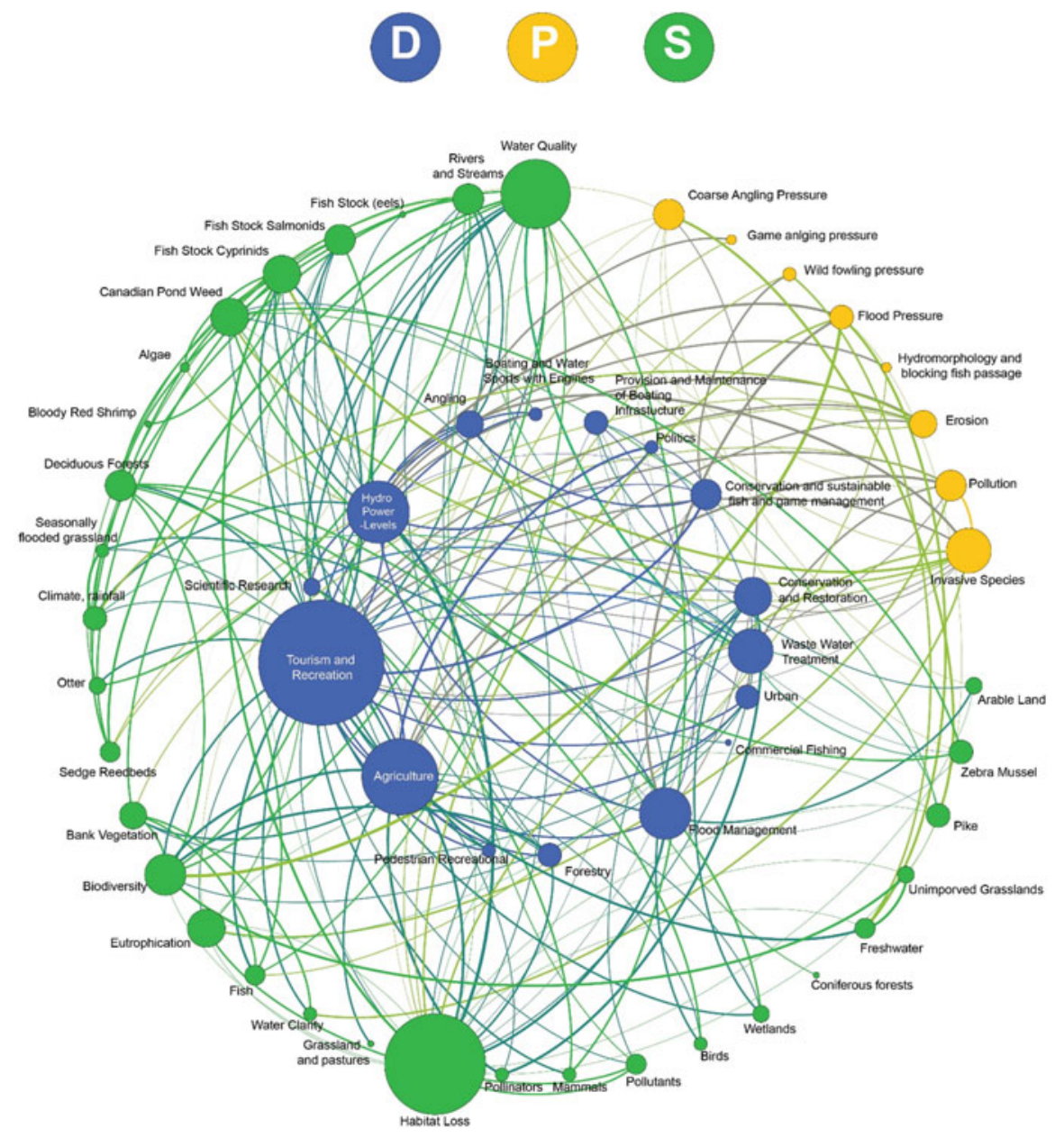

Fig. 3 Combined Fuzzy Cognitive map showing all concepts (nodes, circles) identified and relationships (lines, edges) between them based on the stakeholder workshop. Concepts are scaled according to the number of relationships with other concepts. Colours represent different components of the DPSIR framework. D = Drivers, $\mathrm{P}=$ Pressures, $\mathrm{S}=$ State (See Elliott and O'Higgins 2020)

and recreation and water quality are highly connected. Flood management, hydropower and invasive species are also seen to be highly connected to other components. Table 1 summaries the results of the sensitivity analysis conducted on the consensus FCM. Overall the model component which was most sensitive to alterations in the system was water quality showing relatively large responses to agriculture, forestry, IAS and tourism. The negative relationship between agriculture and water quality represents the strongest interaction in the whole model. Habitats had the strongest positive affect on water quality. In turn water quality had positive 
effects on habitat and biodiversity. The model illustrates the central importance of water quality to stakeholders, and the range of effects that water quality plays including positive effects on Habitat, Biodiversity and tourism, as well as its sensitivity to a range of drivers, but in particular agriculture. On this basis, the strong negative relationship between agriculture and water quality was used as the basis for identification of potential mitigation measures and the economic costings.

The adjustment of lake levels, which emerged as a potential management option for control of Elodea, would result in costs to farmers due to the inundation of productive agricultural lands and does not address the water quality of the Lough specifically. Inundation of agricultural land may also produce co-benefits in terms of biodiversity by increasing the area of semi natural riparian habitats. Maintaining the Lough at higher levels during summer may also result in benefits to the hydroproduction sector enabling increased generation capacity. Figure 4 shows the area of land inundated by raising water levels by $1.2 \mathrm{~m}$ as well as the marginal changes in area of land inundated. The overall cost of compulsory purchase of the potentially inundated areas was just over $£ 2 \mathrm{~m}$. In the absence of compulsory purchase the total costs to farmers in terms of lost annual productivity due to inundation was under $£ 0.5 \mathrm{~m}$.

A range of nutrient abatement measures were also considered. There are many potential mechanisms to decouple agricultural activity from water quality impacts. The economic analysis summarised in Table 2 illustrates how a number of cost saving BMPs (negative costs) can save money to individual farms while also contributing to reduced nutrient loading. The target of 30\% reduction in P loading can be met by implementing the first 6 measures sequentially with an overall cost of $£ 15 \mathrm{~m}$ for the whole catchment.

\section{Discussion}

A range of techniques were employed to understand the Lough Erne SES, these included fuzzy cognitive mapping to combine individual stakeholder groups perception of the systems into an agreed and dynamic model of system behaviour, and more mechanistic GIS-based modelling approach to understand the effects of specific management measures on other activities within the catchment, as well as valuation of potential measures. In combination, these methods revealed a system which is highly complex and where incomplete knowledge is the rule. Nevertheless, the combination of simple techniques in co-design with stakeholders enabled the development of a consensus view of the system identifying eutrophication as a priority problem, with a range of potential measures for management of pond weed in the system also being identified. Ultimately the potential measures were reduced to a single metric of cost effectiveness to enable stakeholders in Lough Erne to consider the relative merits of the measures identified.

The problem of management of Elodea in Lough Erne is not a simple one. The problems of eutrophication are well understood to be an underlying cause for the 


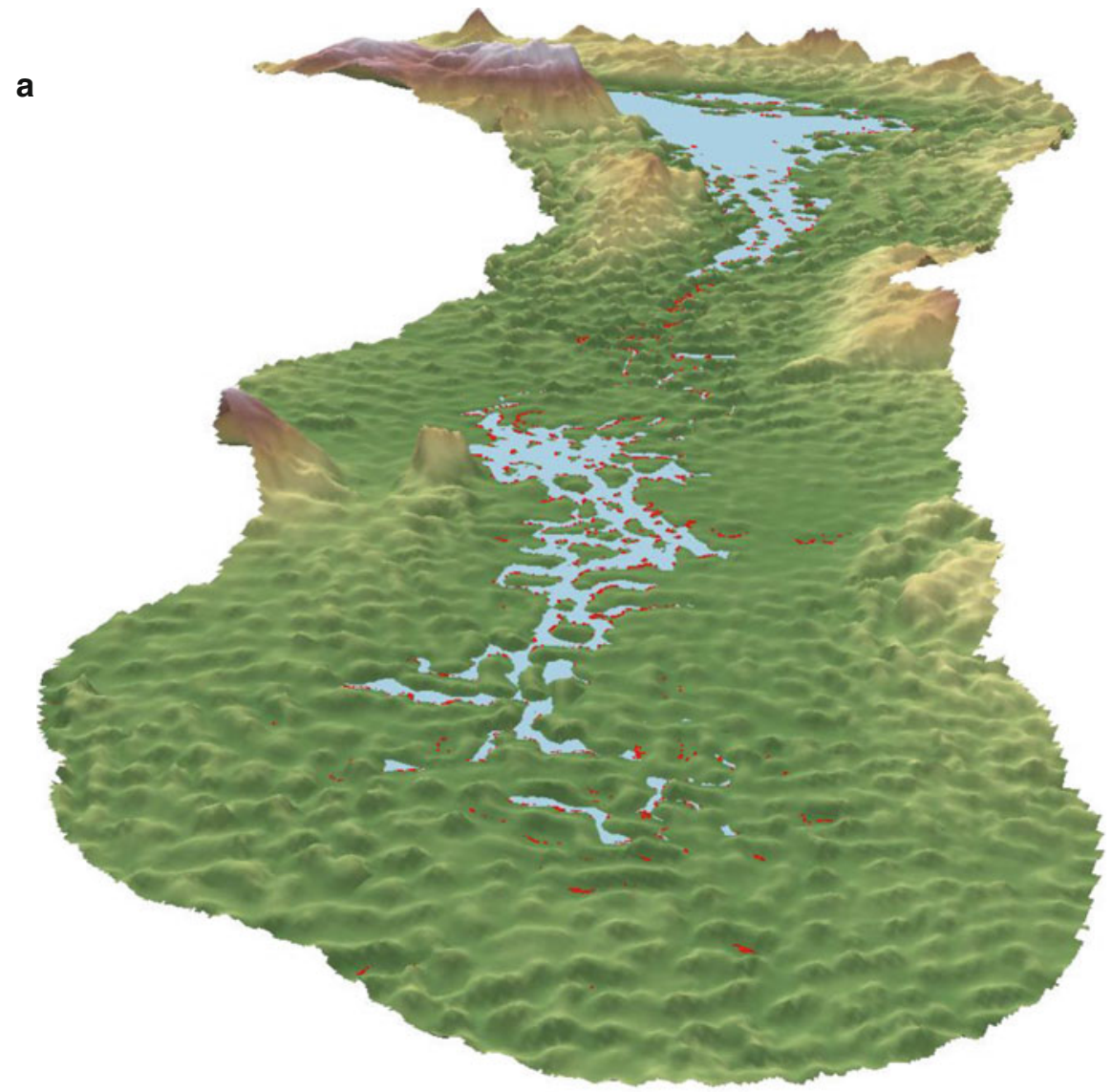

b

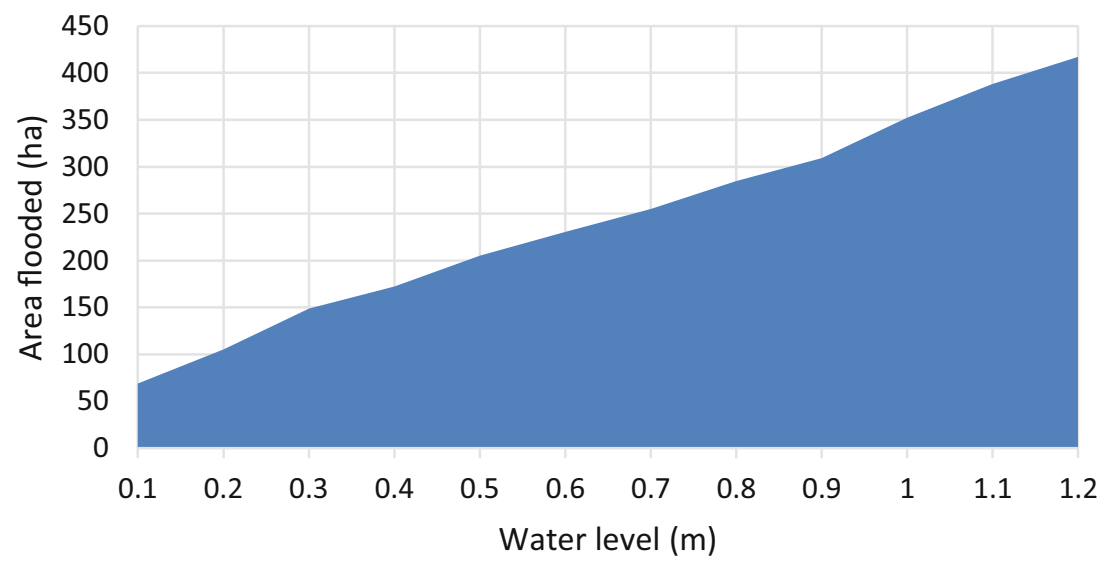

Fig. 4 (a) 3D visualisation of modelled areas of inundation based on raising the lake level by $1.2 \mathrm{~m}$ (b) cumulative area of inundation with increasing water level 
Table 2 Cost Efficiency (CE) and percentage reduction in Phosphorus from a range of agricultural Best Practice Measures

\begin{tabular}{l|l|r|c}
\hline \multicolumn{2}{l}{ Nutrient reduction measure } & CE ratio $^{\mathrm{a}}$ & P Loss $^{\mathrm{b}}$ \\
\hline 1 & Integrate fertiliser and manure nutrient supply & -472.44 & 0.10 \\
\hline 2 & Reduce fertiliser application rates; 20\% Reduction P & -5.25 & 3.10 \\
\hline 3 & Do not apply P fertilisers to high P index soils & -2.62 & 6.00 \\
\hline 5 & Do not spread farmyard manure to fields at high-risk times & 0.98 & 21.04 \\
\hline 6 & Do not apply manure to high-risk areas & 2.25 & 26.57 \\
\hline 7 & Transport manure to neighbouring farms 5 km & 2.69 & 56.68 \\
\hline 8 & Establish and maintain artificial (constructed) wetlands & 2.86 & 74.87 \\
\hline 9 & Use a fertiliser recommendation system & 3.17 & 75.63 \\
\hline 10 & Site solid manure heaps away from watercourses and field drains & 5.25 & 76.36 \\
\hline 11 & Transport manure to neighbouring farms 20 km & 5.25 & 77.07 \\
\hline 12 & Move feed and water troughs at regular intervals & 5.57 & 86.47 \\
\hline 13 & Do not apply fertiliser to high risk areas & 5.85 & 88.36 \\
\hline 14 & Site solid manure heaps on concrete and collect the effluent & 7.87 & 88.83 \\
\hline 15 & Avoid spreading fertiliser to fields at high-risk times & 22.87 & 89.16 \\
\hline 16 & Reduce field stocking rates when soils are wet & 27.36 & 89.38 \\
\hline 17 & Fence off rivers and streams from livestock & 28.43 & 90.34 \\
\hline 18 & Establish riparian buffer strips & 38.40 & 90.53 \\
\hline 19 & Reduce overall stocking rates on livestock farms & 38.40 & 90.72 \\
\hline 20 & Loosen compacted soil layers in grassland fields & 54.05 & 94.15 \\
\hline 21 & Allow field drainage systems to deteriorate & 85.04 & 94.21 \\
\hline 22 & Reduce the length of the grazing day or grazing season & 177.85 & 94.27 \\
\hline
\end{tabular}

${ }^{a} \mathfrak{f} / \%$ Reduction in P loss/ha, NPV/ha over an 8-year period. Discount rate 3.5\%

${ }^{\mathrm{b}}$ Farm level per ha

proliferation of Elodea in the Erne system. Eutrophication is directly related to excess nutrients ( $\mathrm{P}$ particularly) loading to the lake associated with fertilizer use by agriculture, one of the main socio-economic sectors in the region; fortunately, there are many well-known management measures which can be taken to reduce excess nutrient loading. The fact that some improvement in water quality can be achieved while also saving money for farmers provides a powerful justification for taking measures such as identified in items 1-6 of Table 2, thereby improving the efficiency of farms while also yielding environmental benefits for other stakeholders using or enjoying Lough Erne. However effecting change in agricultural practices is beset by governance challenges relating to the implementation of the European Common Agricultural Policy in two separate jurisdictions, where nutrient emissions occur in both the Republic and Northern Ireland but the environmental and social impacts of eutrophication effects are experienced disproportioantely in Northern Ireland. While there are clearly efficiencies to be achieved, the structuring of the Common Agricultural Policy and its single farm payments do not necessarily effectively promote this efficiency. While improved and cost-saving farming practices may reduce nutrient emissions to the Lough, the legacy effects of historic 
pollution combined with the recycling of nutrients by zebra mussel are likely to cause time-lags between measures and their effects.

By contrast, the proposal to manage lake levels, represents a relatively "quickfix". However this proposal also represents an unknown quantity in terms of effectiveness and projected economic costs due to the consequent loss of farm land and productivity. The response of Elodea may not be as simple as reduced growth due to light limitation, and there is also potential for the existing weed to float to the surface resulting in continued nuisance for recreational activity. In reality the effectiveness of water-level management on Elodea are still uncertain, while the consequences to farm productivity are quite certain. Any future alteration of lake levels to control pond weed will therefore be an exercise in adaptive management or learning-by-doing.

While FCM highlighted clear and shared priorities for stakeholders, concerns for co-benefits, in terms of multiple ecosystem services that the lake ecosystem provides, did not emerge explicitly using the methods here. For example, many regulation and maintenance services are inherently valued by people but are often not prioritised compared to services linked to commercial concerns. However, participants did clearly value habitats and biodiversity. Increasing water levels, leading to an increase in the area of temporally flooded riparian habitats, or reducing nutrient inputs from agriculture, could enhance biodiversity and the supply of associated ecosystem services. The addition of holistic methods, such as the linkage framework approach proposed in (Robinson and Culhane 2020), could help to highlight other important services or elements of the SES that might influence the way management measures are evaluated.

\section{Conclusions (Learning by Doing)}

The current state of the Lough Erne SES results from a very long history of human use, conflict and alteration of lake and watershed ecosystems dating back for millennia. The modern Lough is a highly valued ecosystem which provides multiple benefits to humans yet also suffers from a range of chronic and acute environmental problems. European environmental legislative requirements for the Lough are not fully integrated into the management practices of the Lough, and the recent regulation on Invasive Alien Species adds an additional burden of management. Of the aquatic species listed in the regulation and found in the Lough Erne catchment, only one, Elodea nutalli (Nutall's pond weed) has had significant economic impacts to date.

A mixture of common and popular software as well as a range of free and open access tools was used to develop a bespoke methodology suited to a very specific local problem based on the perspectives, perceptions and using the language of interested stakeholders. Graphical output of the FCM was useful in communicating with stakeholders and in developing consensus on the main causes of the weed problem, while the resulting simplified model provided justification to focus the 
analysis on nutrients and eutrophication. Loose coupling of models allowed flexibility. Ultimately more complex ecological models including detailed biogeochemical components would be required to accurately predict the outcome of management measures. However, the utility of our simple approach is that it can promote understanding of trade-offs and represents a forum for interested stakeholder to contribute their knowledge to the management process. This is in itself a vital component of environmental management-since it is people who make the decision on what measures are to be taken. What our approach lacks in analytical complexity or data-driven robustness of more complex modelling techniques (many examples of which can be found in this book) it makes up for in terms of low-cost and ease of application with stakeholders when addressing a specific problem in a specific location. The co-design of the FCM with stakeholder enabled effective communication of complexity of the Lough Erne SES and trade-offs among environmental management options.

Integrated, ecosystem-based management approaches to the management of Lough Erne enable consideration of multiple primary activities and their pressures and provide a basis to meet multiple environmental as well as social and economic objectives. The transboundary nature of the Lough Erne catchment is a barrier to truly integrated management of the catchment, and the political boundaries between the two jurisdictions appear to be becoming more pronounced as the UK is set to leave the European Union. The Erne Drainage and Development Act (1950) (EDDA) was an early example of cross-border cooperation and succeeded because there were mutual benefits to be gained in the two jurisdictions. Changes to the management regime of the lake levels (within the legal limits of the EDDA) offer one opportunity for the management of the system which could continue to provide benefits to users of the Lough Erne SES on both sides of the border and could act as a focus for continued cross-border cooperation. While the inclusion of farmers within any of these management decisions is paramount, and these were notably missing from our stakeholder groups, our stakeholder approach did provide a valuable opportunity for cross border cooperation and collaboration which is one vital element in future management of the Lough Erne system.

While current EU environmental regulation provides a common cross-border framework for environmental management in the Lough Erne catchment across an international boundary, the future basis for such cooperation is unclear. The UK is currently presently in the process of leaving the European Union and the current political and economic basis for environmental regulation, as well as for enabling and subsidising agricultural production, is unlikely to remain as it is, while the potential future alternatives are largely unknown. Major changes in the social system comprising primary activities as well as the norms and values enshrined in environmental laws and regulations may be on the way. The effects of these changes on a social ecological system already characterised by overwhelming complexity cannot be foretold. 


\section{References}

Battarbee, R. W. (1986). The Eutrophication of Lough Erne inferred from changes in the diatom assemblages of $210 \mathrm{~Pb}$ and $137 \mathrm{Cs}$ - dated sediment cores. Proceeding of the Royal Irish Academy Section B: Biological, Geological and Chemical Science, 86b, 141-168.

CBD. (2014). Aichi biodiversity targets. Retrieved from https://www.cbd.int/sp/targets/.

Cuttle, S. P., Macleod, C. J. A., Chadwick, D. R., Scholefield, D., Haygarth, P. M., Newell-Price, P., Harris, D., Shepherd, M. A., Chambers, B. J., \& Humphrey, R. (2007). An inventory of methods to control diffuse water pollution from agriculture. DEFRA-Project ES0303.

EC. (2000). Directive 2000/60/EC of the European Parliament and of the Council of 23 October 2000 establishing a framework for community actions in the field of water policy. Official Journal of the European Communities, L327, 1.22.12.2000.

EC. (2014). Regulation (EU) no 1143/2014 of the European Parliament and of the council of 22 October 2014 on the prevention and management of the introduction and spread of invasive alien species. Official Journal of the European Union, 2014, L317/35.

Elliott, M., \& O'Higgins, T. G. (2020). From the DPSIR, the D(A)PSI(W)R(M) emerges... a butterfly-'protecting the natural stuff and delivering the human stuff'. In T. O'Higgins, M. Lago, \& T. H. DeWitt (Eds.), Ecosystem-based management, ecosystem services and aquatic biodiversity: Theory, tools and applications (pp. 61-86). Amsterdam: Springer.

Gallagher, K., Rosell, R., Vaughan, L., McElarney, R., Campbell, W., O’Kane, E., \& Harrod, C. (2015). Hemimysis anomala G.O. Sars, 1907 expands its invasive range to Northern Ireland. BioInvasions Records, 4, 43-46.

Holling, C. S. (1978). Adaptive environmental assessment and management. Chichester, UK: Wiley.

Kelly, J., Tosh, D., Dale, K., \& Jakcson, A. (2013). The economic cost of invasive and non-native species in Ireland and Northern Ireland. Report prepared for the Northern Ireland Environment Agency and the National Parks and Wildlife Service as part of Invasive Species Ireland, $86 \mathrm{pp}$.

Kelly, R., Harrod, C., Maggs, C. A., \& Reid, N. (2015). Effects of Elodea nuttallii on temperate freshwater plants, microalgae and invertebrates: Small differences between invaded and uninvaded areas. Biological Invasions, 17, 2123-2138.

Lafferty, B., Quinn, R., \& Breen, C. (2006). A side-scan sonar and high resolution Chirp sub-bottom profile study of the natural and anthropogenic sedimentary record of Lower Lough Erne, Northwestern Ireland. Journal of Archaeological Science, 33, 756-766.

Lago, M. (2009). An investigation of regulatory efficiency with reference to the EU water framework directive: An application to Scottish agriculture. PhD thesis, University of Edinburgh.

Maguire, C., Rossell, R., \& Roberts, D. (2006). Management of the impacts of zebra mussels in Northern Ireland and determination of the effects on fish populations in Lough Erne through alteration of food web. Environment and Heritage Service Research and Development Series 06/25, pp. 51.

Mee, L., Cooper, P., Kannen, A., Gilbert, A. J., \& O’Higgins, T. (2015). Sustaining Europe's seas as coupled social-ecological systems. Ecology and Society, 20(1), 1. https://doi.org/10.5751/ES07143-200101.

Minchin, D., Caffrey, J. M., Haberlin, D., Germain, D., Walsh, C., Boelens, R., \& Doyle, T. K. (2016). First observations of the freshwater jellyfish Craspedacusta sowerbii Lankester, 1880 in Ireland coincides with unusually high water temperatures. BioInvasions Records, 5, 67-74.

Moore, D., \& More, A. G. (1866). Cybele Hibernica (p. 538). Dublin University Press.

Özesmi, U., \& Özesmi, S. L. F. (2004). Ecological models based on people's knowledge: A multistep fuzzy cognitive mapping approach. Ecological Modelling, 176, 43-64.

Robinson, L., \& Culhane, F. (2020). Linkage frameworks: An exploration tool for complex systems. In T. O’Higgins, M. Lago, \& T. H. DeWitt (Eds.), Ecosystem-based management, ecosystem services and aquatic biodiversity: Theory, tools and applications (pp. 213-234). Amsterdam: Springer. 
Robinson, L. A., Blincow, H. L., Culhane, F. E. L., \& O’Higgins, T. (2019). Identifying barriers, conflict and opportunity in managing aquatic ecosystems. Science of the Total Environment, 651, 1992-2002.

Rosell, R. (2001). Monitoring fish populations in lower Lough Erne, Northern Ireland: Applicability of current methods and implications for future monitoring under the EC Water Framework Directive. Freshwater Forum, 16, 65-81.

Rosell, R. S., Maguire, C. M., \& McCarthy, T. K. (1999). First reported settlement of zebra mussels Dreissena polymorpha in the Erne system, Co. Fermanagh, Northern Ireland. Proceedings of the Royal Irish Academy, 98(B), 191-193.

Went, E. J. (1945). Fishing weirs of the River Erne. The Journal of the Royal Society of Antiquaries of Ireland., 75(4), 213-223.

Open Access This chapter is licensed under the terms of the Creative Commons Attribution 4.0 International License (http://creativecommons.org/licenses/by/4.0/), which permits use, sharing, adaptation, distribution and reproduction in any medium or format, as long as you give appropriate credit to the original author(s) and the source, provide a link to the Creative Commons licence and indicate if changes were made.

The images or other third party material in this chapter are included in the chapter's Creative Commons licence, unless indicated otherwise in a credit line to the material. If material is not included in the chapter's Creative Commons licence and your intended use is not permitted by statutory regulation or exceeds the permitted use, you will need to obtain permission directly from the copyright holder. 